\title{
Közgazdasági Szemle
}

\section{LÁSZLÓ CSABA}

A magánnyugdijpénztári rendszer „elszámolása”

SIMONOVITS ANDRÁS

Miért kell a nyugdij-valorizálást és -indexálást pontrendszerrel felváltani?

\section{BENCZES ISTVÁN}

Az curóövezet válságrendezése a liberális kormányköziség elméletének értelmezésében

LUKOVICS MIKLÓS-UDVARI BEÁTA-ZUTI BENCE-KÉZY BÉLA Az önvezetô autók és a felelösségteljes innováció 
Szerkesztőbizottság: a Magyar Tudományos Akadémia Közgazdaság-tudományi Bizottsága

Bélyácz Iván, Benczes István, Benczúr Péter, Berlinger Edina (titkár), Bod Péter Ákos, Chikán Attila, Csaba László, Darvas Zsolt, Erdős Tibor, Farkas Beáta (elnökhelyettes), Fertő Imre, Győrffy Dóra (elnökhelyettes), Halmai Péter, Halpern László, Hámori Balázs, Horváth Julius, Kádár Béla, Király Júlia, Kóczy Á. László, Kónya István (elnökhelyettes), Kornai János, Körösi Gábor, Köszegi Botond, Laki Mihály, Madarász Aladár, Mellár Tamás, Mihályi Péter, Muraközy Balázs, Muraközy László (elnök), Oblath Gábor, Palánkai Tibor, Simai Mihály, Simonovits András, Surányi György, Száz János, Szentes Tamás, Tasnádi Attila, Váradi Balázs, Várhegyi Éva, Vincze János, Voszka Éva, Vörös József, Zalai Ernő

\section{Tanácsadó testület}

Berács József, Csaba László, Kocziszky György, Muraközy László, Simonovits András, Szabó Katalin, Vincze János, Vörös József

Közgazdasági Szemle, LXV. évfolyam, 2018. szeptember

\section{T A R T A L O M}

László Csaba: A magánnyugdíjpénztári rendszer „elszámolása”

Simonovits András: Miért kell a nyugdíj-valorizálást és -indexálást pontrendszerrel felváltani?

Benczes István: Az euróövezet válságrendezése a liberális kormányköziség elméletének értelmezésében

SZEMLE

Lukovics Miklós-Udvari Beáta-Zuti Bence-Kézy Béla: Az önvezető autók és a felelősségteljes innováció

\section{KÖNYVISMERTETÉS}

Simai Mihály: A harmadik évezred nyitánya. A zöld fejlődés esélyei és a globális kockázatok (Dobozi István)

A cikkek angol nyelvü tartalmi kivonata

\footnotetext{
A Közgazdasági Szemle Alapítvány alapítói és támogatói

Magyar Nemzeti Bank, MTA Könyv- és Folyóirat-kiadó Bizottsága

Föszerkesztö: Halm Tamás

Rovatvezetők: Balatoni András (makroökonómia), Kiss Hubert János (mikroökonómia), Rosta Miklós (intézményi és közösségi gazdaságtan)

Szerkesztő: Patkós Anna • Elektronikus kiadás: Sok Ödön

Tipográfus: Kempfner Zsófia • Szöveg-elökészítés és grafikai munkák: Pető Ildikó
} 


\section{LUKOVICS MIKLÓS-UDVARI BEÁTA-ZUTI BENCE- KÉZY BÉLA}

\section{Az önvezető autók és a felelősségteljes innováció}

Napjaink uralkodó globális megatrendje, a digitalizáció figyelemre méltó megoldásokkal kívánja az emberiség életét megkönnyíteni. Ezek közül is kiemelkednek az önvezető autók, amelyeket a szakirodalom a radikális innovációk közé sorol, utalva arra, hogy az önvezető autók tömeges elterjedése nemcsak az emberiség mindennapi életét, de - többek között - a városok szerkezetét és a közlekedés számos jellemzőjét is gyökeresen megváltoztatja. Az önvezető autók fejlesztése az utolsó tesztfázisban van: jelenleg már 76 város közútjain, az utcai forgalomban végzik a technológia utolsó simításait. E radikális innováció azonban megosztja a közvéleményt, aminek leginkább az az oka, hogy az önvezető jármüvek a megbízhatóságukon túl számos - társadalmi, etikai, környezeti és gazdasági - kérdést vetnek fel, amelyekre jelenleg még nincsenek válaszok. E tanulmány célja, hogy feltárja e témakör leginkább vitatott kihívásait, amelyek jelenlegi ismereteink szerint extrém módon fogják felforgatni minden civilizációban élő ember napi életvitelét. Az önvezető autók kérdéskörét a felelősségteljes innováció keretrendszerébe ágyazzuk, amelynek segítségével a feltárt kihívások kezelhetők.

Journal of Economic Literature (JEL) kód: O14, O18, O33.

Napjaink meghatározó jelensége a negyedik ipari forradalom, amely az infokommunikációs technológián alapuló rendszerek és hálózatok szerepét hangsúlyozó folyamat (Kovács [2017a]), amely akár a globális munkamegosztást is átalakíthatja (Lengyel és szerzötársai [2016]). Az ipar 4.0 alapját a széles körben elterjedt és hozzáférhető internet, a mesterséges intelligencia és a gépi tanulás, valamint a zöldenergia adják. Főbb meghatározó elemei pedig fizikai (önvezető autók, 3D nyomtatás, fejlett robotok), digitális („dolgok internete”) vagy biológiai (géntechnológia) tényezők lehetnek (Kuruczleki és szerzőtársai [2016], Prisecaru [2016]). E globális, az élet legtöbb szegmensét érintő, gyors ütemű változásra mint komoly potenciált

Lukovics Miklós egyetemi docens, SZTE Gazdaságtudományi Kar (e-mail: miki@eco.u-szeged.hu). Udvari Beáta egyetemi adjunktus, SZTE Szegedi Tudományegyetem Gazdaságtudományi Kar (e-mail: udvari.beata@eco.u-szeged.hu).

Zuti Bence PhD-hallgató, SZTE Közgazdaságtani Doktori Iskola (e-mail: zuti.bence@gmail.com). Kézy Béla városfejlesztési szakértő, Megakom (e-mail: kezy@megakom.hu).

A kézirat első változata 2018. március 8-án érkezett szerkesztőségünkbe.

DOI: http://dx.doi.org/10.18414/KSZ.2018.9.949 
rejtő jelenségre óriási figyelem összpontosul, számos kutatás foglalkozik jellemzőivel (Kovács [2017a]).

A negyedik ipari forradalom egyik radikális innovációja az önvezető autó. ${ }^{1}$ E jármüvek már teljesen automatizáltak, és bármilyen körülmények között képesek megtartani az irányítást, tehát emberi beavatkozás nélkül is képesek közlekedni. $\mathrm{Az}$ önvezető autók a napjaink részévé vált önvezető metrókkal ellentétben már nem kötött pályán mozognak, és mivel a cél a teljes automatizáltság, így a digitalizáció mellett lényegesen nagyobb szerepet kap e járművek mesterséges intelligenciája is. Erről az innovációról jelenleg két dolgot emelhetünk ki: 1. a prognózisok jövőképe szerint alapjaiban változtatja meg az emberiség jövőjét; 2 . sokkal elöbbre tart, mint ahogy azt a közvélemény gondolná, hiszen jelenleg már 76 város közútjain folyik utolsó fázisú tesztelés.

Ugyanakkor ez a radikális innováció jelentősen megosztja a világ társadalmát, aminek legfóbb oka talán az, hogy az ipar 4.0 vívmányainak a pozitív szinergikus hatásai mellett nem szándékolt következményei (például biztonság, paradox fogyasztási mintázat, automatizálási következményei) is lehetnek (Kovács [2017b]), amelyekre jóval kevesebb figyelem irányul. Az önvezető autók széles körü elterjedésével megváltozik az autóipar és a kapcsolódó iparágak teljes értéklánca, az emberek közlekedési eszközökhöz való viszonya, a mindennapi közlekedés. Mindez pedig - az önvezető autók megbízhatóságán túl - számos társadalmi, etikai, környezeti és gazdasági kockázatot hordoz magában, amelyekre jelenleg még nincsenek válaszok. Ezek a kérdések szoros összefüggésben vannak a felelősségteljes kutatás és innováció kérdéskörével, amelynek célja a kutatás-fejlesztési és innovációs folyamatok nem szándékolt hatásainak minimalizálása. Így kutatásunk célja, hogy az önvezető autó mint radikális innováció leginkább vitatott társadalmi kockázatait feltárjuk, és a felelősségteljes innováció keretrendszerét használva ezekre megoldási lehetőségeket kínáljunk.

A cikk első részében a negyedik ipari forradalom egyik mozgatórugóját, a digitalizációt mutatjuk be. Ezt követően definiáljuk a nem kötött pályán mozgó önvezető járműveket, ismertetjük társadalmi megítélésüket, és részletezzük a várható pozitív jövőkép mellett a velük kapcsolatban felmerült kockázatokat is. A cikk második blokkjában a felelösségteljes innováció fogalomkörét használva lehetséges válaszokat kínálunk a nem kötött pályán mozgó önvezető jármủvekkel kapcsolatban felmerült kockázatokra.

\section{A negyedik ipari forradalom - a digitalizáció felértékelődése}

A negyedik ipari forradalom (ipar 4.0) az 1970-es években jelentős mértékben felgyorsult információs technológia fejlődésére (harmadik ipari forradalom) épül, azonban összetettsége miatt nem lehet egy-egy kulcsfelfedezést vagy kulcsjelenséget

\footnotetext{
${ }^{1}$ Ebben a tanulmányban az önvezető autó kifejezést egységesen alkalmazzuk a cikkben később bemutatott automatizáltsági szintek 5. szinTjén álló autókra, buszokra, kamionokra, de idetartoznak a kötött pályán közlekedő önvezető járművek (például metró) is.
} 
kiemelni, amely később a radikális változásokat előidézte. ${ }^{2}$ Az ipar 4.0 már nemcsak a különböző iparágak termelési folyamatait befolyásolja közvetlenül, hanem a természetes személyek életét is (Schmidt és szerzötársai [2015]). Az ipar 4.0 definíciói sokszínűek (lásd Davies [2015], Kovács [2017a], Nagy [2017], Pfohl és szerzötársai [2015], Schuh és szerzőtársai [2017], Schmidt és szerzőtársai [2015] vagy Smit és szerzőtársai [2016]), mi a tanulmányunkban Pfohl és szerzőtársai [2015] meghatározására támaszkodunk, amely szerint az „,ipar 4.0 az értéklánchoz köthető romboló innovációk összessége, amely a digitalizáció trendjeit, az automatizációt, transzparenciát, mobilitást, modularizációt, hálózati együttmüködéseket és a termékek, folyamatok társadalmasítását célozza meg" (37. o.).

Az ipar 4.0 a virtuális és materiális térben párhuzamosan, de egymást kiegészítve zajlik, a mesterséges intelligenciára, valamint az okoseszközök és emberek rendkívül sürü összekapcsoltságára is épít (Yoon [2017]). Erre alapozva várhatóan kilenc meghatározó technológiai ágazat kapcsán teremti a legnagyobb hozzáadott értéket (Kovács [2017a] 825. o.): Big Data-analitika, autonóm gépek, robotok, szimulációk, horizontális és vertikális rendszerek integrálása, Internet of Things, kiberbiztonság, felhőtechnológia, additív gyártás, kiterjesztett valóság.

Napjaink technológiai újításait egyértelmüen a digitalizáció határozza meg. Maga a digitalizáció egy olyan önkatalizáló folyamat, mely az élet minden aspektusához hozzárendel egy virtuális vetületet, gazdasági aspektusból folyamat- és szervezetfejlesztési lehetőségeket nyújt az érintetteknek, társadalmi aspektusból pedig lehetővé teszi a folytonos adatcserét emberek és eszközök között az infokommunikációs infrastruktúrákra és az internetre támaszkodva (Capgemini [2011], Krishna [2017], OW [2014]). Tehát olyan gazdasági-társadalmi környezet formálódik napjainkban, amelyben az okoseszközök folyamatosan kommunikálnak egymással, valamint a fogyasztókkal, párhuzamosan érintve a materiális és virtuális világot (Hwang [2016], Kagermann és szerzőtársai [2016], Pfohl és szerzötársai [2015]). Az életünk nagy része a virtuális, digitális térben is jelen van, az online jelenlétünk és az okoseszközökkel való összekapcsoltságunk az elmúlt évtizedben radikálisan megnőtt (OW [2014]).

Az ipar 4.0 alapját jelentő digitalizáció jelentősen megváltoztatta a 21. század világképét a 20. századéhoz képest. Egyrészt, a világ egészét összekötik a kommunikációs csatornák, radikálisan felértékelődnek az immateriális javak, a tudásintenzív folyamatok elöretörésével a tőkeintenzív folyamatok dominanciája háttérbe szorul. Másrészt, egyre több adatot generálunk és használunk fel elemzésekhez, becslésekhez és a legkülönfélébb döntések meghozatalakor. Harmadrészt, az új digitális platformok lehetőséget adnak arra, hogy hatékonyabban és átláthatóbban érjük el a piacainkat és kommunikáljunk az érintettekkel. Ezáltal a globális piac már nemcsak a multinacionális vállalatok ,játszótere”, hanem a kis- és középvállalatok, a startupok, egyéb vállalkozók

\footnotetext{
${ }^{2}$ Az első ipari forradalmat (18. század vége, 19. század eleje) követően a vízzel, illetve gőzzel müködtetett gépek használata terjedt el, főként a termelő iparágakban. A második ipari forradalom (20. század eleje) legjelentősebb innovációja az elektromos áram által vezérelt, tömegtermelést lehetővé tevő gépsorok bevezetése. A harmadik ipari forradalom (1970-es évek eleje) kulcsinnovációi, az elektronikus eszközök és az informatika feltárt lehetőségei által egyre inkább elkezdtek terjedni az automatizált rendszerek (Kovács [2017a]).
} 
és szabadúszók is képessé válnak határokon átnyúló projektekben való rendszeres részvételre, jóval könnyebben, mint bármikor korábban (Kovács [2017b], Manyika és szerzőtársai [2016]). Radikális változásokra kell számítanunk a mindennapi életünkben (Schwab [2017]). Ebből fakadóan a jelenlegi társadalmunk és gazdaságunk az elkövetkezendő évtizedben várhatóan teljesen új környezetbe kerül. Ebben a gyors folyamatban vitathatatlan, hogy aki későn lép, minden bizonnyal lemarad, és hátrányba kerül a piac többi szereplöjével szemben (WEF [2017], Magruk [2016], OW [2014], Schmidt és szerzőtársai [2015], Schuster és szerzőtársai [2015a], [2015b]).

Az ipar 4.0 jelenleg is számos kormányzati és gazdaságfejlesztési stratégia alapkövét jelenti (Blanchet-Rinn [2016], Kagerman és szerzőtársai [2016], Nagy [2017], Nagy-Lengyel [2016], Smit és szerzőtársai [2016], Wübbeke és szerzőtársai [2016]). E stratégiák közös pontja és végső célja a digitalizációban rejlő lehetőségek gyakorlati adaptációja, ahol vezérmotívumként jelennek meg a gazdasági, társadalmi és környezeti fenntarthatósági szempontok is (Klitou és szerzőtársai [2017], Kovács [2017b]), hiszen a digitalizáció eredményeként létrejövő újfajta üzleti modellek, társadalmi és gazdasági berendezkedések olykor rombolva innoválnak (Blix [2015], OECD [2017a], OECD [2017b]).

A digitalizáció figyelemre méltó megoldásokkal kívánja az emberiség életét megkönnyíteni, amelyek közül az önvezető autók kiemelkednek. Ezt az újítást a szakirodalom radikális innovációként kategorizálja, utalva arra, hogy az önvezető autók tömeges elterjedése nemcsak az emberiség mindennapi életét, hanem - többek között - a városok szerkezetét és a közlekedés számos tényezőjét is gyökeresen megváltoztatja.

\section{Az önvezető autók megjelenése, társadalmi megítélése és kockázatai}

Több évtizednyi kutatás-fejlesztési tevékenység eredményeként jutottunk el oda, hogy a korábban pusztán emberi irányítással müködtetett jármüvek egyre inkább közelítenek a teljes automatizációs állapothoz, és önvezetőnek tekinthetjük őket (Giffi és szerzőtársai [2017], Yeomans [2014]). A digitalizációnak köszönhetően napjaink autóit a legkülönfélébb szenzorokkal szerelik fel annak érdekében, hogy biztonságosabbá tegyék és új szintre emeljék a közlekedést, a szállítást és a jármüvekhez köthető egyéb ipari tevékenységek kivitelezését (SMMT [2017a], [2017b], Yeomans [2014]). Az önvezetö, automatizációs vagy vezető nélküli technológiák nemcsak személygépjármüvekhez köthetök, hanem például a drónok, vonatok, hajók, buszok, ürhajók, valamint egyéb teherszállító jármüvek esetén is alkalmazhatók (Yeomans [2014]).

Jelen tanulmányban a következő pontban definiált önvezető autókra fektetjük a hangsúlyt, ugyanis ezeket olyan radikális innovációnak tekintjük, amely a civilizációban élő teljes népességet érintik, azonban az információs bizonytalanság mellett a társadalmi, etikai kockázatok is érezhetően megjelennek. Továbbá a legnagyobb autógyártók már saját $\mathrm{K}+\mathrm{F}+\mathrm{I}$ projektjeiket valósítják meg az önvezető autók terén, így e technológia tömeggyártásának bevezetése egyre közelebb van. Ennek értelmében fontos 
hangsúlyt fektetni annak vizsgálatára, hogy milyen az önvezető autók megítélése az eddigi szakmai elemzések alapján, illetve kiemelten kell kezelni az önvezető autók nyújtotta lehetőségek mellett a bennük rejlő kockázatok lehető legteljesebb körü felmérését.

\section{Az önvezető autók}

Az önvezető autók (beleértve a nem kötött pályán mozgó buszokat és kamionokat is) meghatározása során az „önvezetö” jelző megértéséből szükséges kiindulni, amihez az automatizáció szintjeinek megismerése jelent megfelelő alapot. E szintek kategorizálása szervezettől függően változhat, a legmeghatározóbbak az Egyesült Államok közlekedési felügyelete (National Highway Traffic Safety Administration, NHTSA) és az SAE (Society of Automotive Engineers), valamint a német BASt (Bundesanstalt für Straßenwesen) csoportosítása. Ebben a cikkben az SAE keretrendszerét tekintjük át, mert ez differenciálja legmélyebben az automatizáció szintjeit. Az SAE által meghatározott automatizációs szintek a következök (Glancy [2015], ITF [2015]):

0. SZINT: AZ AUTOMATIZÁCIÓ TELJES HIÁNYA • A jármü irányítása kizárólag az emberi vezető kezében van, annak teljes irányítása alatt áll.

1. SZINT: GÉPJÁRMUUVEZETÉS-TÁMOGATÁS•A támogató rendszerek képesek arra, hogy specifikus információkat nyújtsanak a vezetőnek, és átvegyék vagy a sebességváltoztatáshoz, vagy a kormányzáshoz kapcsolható műveleteket, de nem mindkettőt egyszerre. A jármü továbbra is emberi irányítás alatt áll.

2. SZINT: RÉSZlegeS AUTOMATIZÁLtSÁG - A támogató rendszerek már képesek arra, hogy a sebességváltoztatáshoz és a kormányzáshoz kapcsolható müveleteket átvegyék, akár egyszerre is. A jármü azonban ebben az esetben is emberi irányítás alatt áll.

3. SZINT: Feltételes AUtomatizÁltság - A jármü rendszere már képes arra, hogy átvegye az irányítást a dinamikus vezetési műveletek felett (laterális és longitudinális kontroll), ugyanakkor a rendszer azt feltételezi, hogy szükség esetén a jármü vezetője képes arra, hogy reagáljon, és visszavegye az irányítást.

4. SZINT: MAGAS SZINTUU AUTOMATIZÁLTSÁG • A jármü rendszere már képes az irányítás átvételére és annak a dinamikus vezetési műveletek feletti megtartására (laterális és longitudinális kontroll itt is teljesül) akkor is, ha a jármü vezetöje nem képes visszavenni az irányítást.

5. SZINT: TELJES AUTOMATIZÁLTSÁG • A jármü rendszere már bármilyen körülmények között képes megtartani az irányítást, azaz emberi beavatkozás nélkül is képes a közlekedésre.

Kutatásunk során önvezető autón az SAE által definiált 5. szintet értjük, azaz jellemző a teljes automatizáltság. ${ }^{3}$ Az önvezető jármüvek közvetlenül a logisztika és

\footnotetext{
${ }^{3}$ Megjegyezzük, hogy az autók új generációjának más típusai is vannak: az okosjármü (connected vehicle) olyan technológiákkal és szenzorokkal van ellátva, amelyek képesek adatcserére és kommunikációra hasonló okoseszközökkel. Az autonóm jármü (autonomous vehicle) képes arra, hogy emberi
} 
a földi személyszállítás kapcsán jelentenek óriási lehetőséget, továbbá bevezetésük hatással lesz a biztosítási, a biztonságtechnológiai és a jogi területek mellett a munkaerőpiacra is (BLM [2015], CGPS [2017]). Egy ilyen jármünek képesnek kell lennie arra, hogy szenzoraival információt gyüjtsön környezetéről, legyen szó fizikai vagy digitális infrastruktúráról (ITF [2015]). A nemzetközi szakirodalom kutatási irányaiból azonban egyértelmüen leszürhető, hogy az önvezető autók társadalmi megítélése olyan kurrens kérdés, amely alapjaiban határozza meg az egész technológia jövőjét.

\section{Az önvezető autók által generált erőteljes változások}

Az önvezető autók széles körű elterjedésével a legnagyobb, leggyorsabb és legmélyrehatóbb átalakulás megy majd végbe a mobilitás történetében. Corwin és szerzőtársai [2016] négy potenciális forgatókönyvet tart számon a közlekedés jövője kapcsán (1. ábra). Mindegyik forgatókönyv három fő tengely mentén alakul: a jármü feletti kontroll (vezetőközpontú-autonóm), az eszközhatékonyság (alacsony-magas), a jármü feletti tulajdonjog (személyes-közösségi).

1. ábra

A közlekedés jövőjének potenciális forgatókönyvei

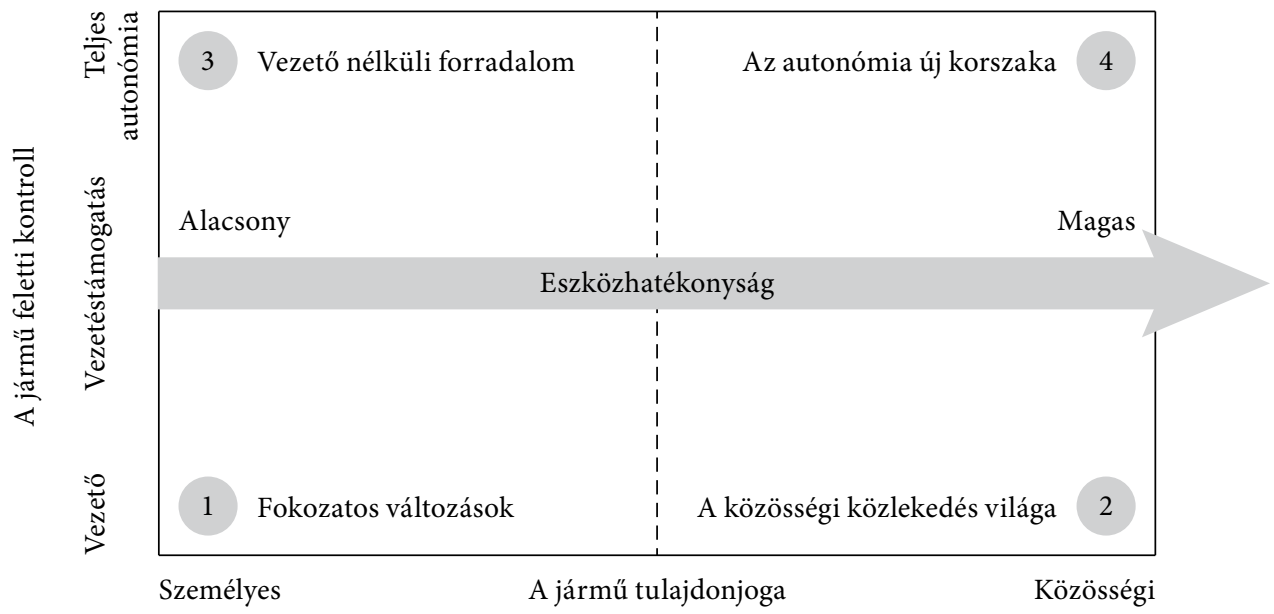

Forrás: Corwin és szerzötársai [2016] (4. o.) alapján saját szerkesztés.

A négy forgatókönyv a következő (Corwin és szerzőtársai [2016] 4. o.):

1. A változások nem erőteljesek, hanem fokozatosak lesznek, és a fogyasztók továbbra is ragaszkodnak majd ahhoz, hogy legyen a saját tulajdonukban jármü. Bár a közlekedést segítő technológiák elterjednek, a teljes autonómia nem fogja jellemezni a járműveket, a kontroll az emberi vezetőnél marad a közeljövőben.

közbeavatkozás nélkül vezesse magát (SMMT [2017b]). A végcél olyan járművek gyártása, amelyek ezeket ötvözik, létrehozva az autonóm okosjármüvet (connected and autonomous vehicles, CAVs). 
2. A közösségi megosztáson alapuló gazdaság (sharing economy) szerepe tovább növekszik, elörevetítve a közösségi közlekedés világát. A várakozások szerint ez a struktúra hatékonyabban kielégíti a közlekedéshez köthető igényeket. Az autót tulajdonló személyek száma folyamatosan csökken majd.

3. Az önvezető technológiák elterjedése növelni fogja a biztonság- és kényelemérzetet, ugyanakkor a fogyasztók továbbra is ragaszkodnak majd ahhoz, hogy az adott jármü tulajdonosai legyenek. E forgatókönyv szerint a személyre szabott jármüvek elterjedése várható.

4. Az új, autonóm korszak az önvezető technológiák és a közösségi gazdaság elterjedése csúcspontjának tekinthető. A várakozások szerint ez a korszak az urbánus térségekből fog indulni, majd a külvárosi és rurális térségekre is kiterjed.

E négy forgatókönyvből három igen jelentős változásokat prognosztizál, és ha egyéb elörejelzéseket is górcső alá veszünk, akkor igen radikális jövőképeket láthatunk. Számtalan elörejelzés azt mutatja, hogy az önvezető autók világszintű elterjedését már a következő évtized első felére várhatjuk, ${ }^{4}$ Arbib-Seba [2017] számításai szerint pedig 2030-ra az utaskilométerek 95 százalékát már flottakezelők által müködtetett, önvezető jármüvek teszik meg az Egyesült Államokban.

Amint a szabályozások lehetővé teszik, az emberek a saját személygépkocsi használata helyett - különösen a városi közlekedésben - a közlekedést szolgáltatásként (Transport as a Service, TaaS vagy Mobility as a Service, MaaS) veszik igénybe, amely - lényeges kényelmi kompromisszumok nélkül - olcsóbb lesz, mint egy saját jármü fenntartása (Keeney [2017], Litaman [2017]). Amennyiben ez bekövetkezik, akkor mindennapi életünk számos területén drasztikus változások várhatók (Arbib-Seba [2017], Keeney [2017], Litaman [2017]).

LOKÁLIS GAZDASÁGI HATÁsOK • Az olcsóbb közlekedéssel elért költségmegtakarítás eredményeként a háztartásoknál addicionális szabadon elkölthető forrás keletkezik, amelynek egy része többletfogyasztásként jelentkezhet a helyi vállalkozásoknál. Bár visszaeshetnek a közlekedésből származó települési bevételek (parkolási díjak, gépjárműadó), mivel azonban a közúti és parkolási infrastruktúrát kevesebb jármü használja majd, ennek fenntartási és fejlesztési költségei is csökkennek.

TÉRHASZNÁlAT, VÁROSI KÖRNYEZET • Mivel az önvezető autók elterjedésével azt prognosztizálják, hogy a közlekedés szolgáltatásként lesz jelen az életünkben, így jelentős nagyságú, értékes városi terek szabadulnak fel. Míg napjainkban egy átlagos személygépkocsi élettartamának 96 százalékát egy helyben parkolva tölti, addig a flottakezelők által müködtetett, önvezetö autók esetében ez az arány várhatóan 50 százaléknál alacsonyabb lesz. Új közösségi terek, parkok jöhetnek létre, de a felszabaduló területeket, létesítményeket az egyre nyomasztóbb lakáshiány enyhítése érdekében is lehet hasznosítani. Összességében tehát a városok kevésbé zsúfolt, sétálhatóbbá, biztonságosabbá és élhetôbbé válnak.

KÖRNYEZETI ÉS EGÉSZSÉGÜGYI HATÁSOK • Az elektromos hajtású önvezető járművekre épülő, közösségi megosztáson alapuló autóhasználat nagyságrendekkel

\footnotetext{
${ }^{4}$ Lásd részletesen az előrejelzéseket az alábbi linken: http://www.driverless-future.com/?page_id=384.
} 
csökkenti a közlekedésből származó károsanyag-kibocsátást, ami nemcsak a városok levegőjét - és ezáltal a városi életminőséget - javítja, de kedvező hatást gyakorol közegészségügyi és gazdasági szempontból is. Az önvezető autók feltehetően biztonságosabbak, mint az emberek által vezetett jármüvek, jelentősen csökken a közlekedési balesetek száma is.

TÁRSADALMI HATÁsoK • A közlekedési rendszerek egyik fontos funkciója az elérhető mobilitás biztosítása mindenki számára. Az önvezető autókra építő, ajtótól ajtóig szolgáltató rendszerek lehetővé teszik a mobilitást azok számára is, akik jelenleg nem engedhetik meg maguknak egy autó fenntartását, vagy éppen nem tudnak vezetni (időskorúak, mozgáskorlátozottak), és a lakóhelyük elhelyezkedése miatt a közösségi közlekedés sem jelent számukra megoldást. Ezáltal pedig az önvezető autók hozzájárulnak a mobilitási korlátokból származó esélyhátrányok kiküszöböléséhez is.

Az önvezető autók gazdasági hatásaira vonatkozóan is több kutatás született már. Montgomery [2018] az önvezető autók használatából eredő magán- és társadalmi hasznokat különböztet meg, és számításai során azzal az előfeltételezéssel élt, hogy az önvezető autók a teljes elérhető jármüflotta 100 százalékát képezik. A magánhasznok önvezető autók vásárlására, valamint önvezető autók szállítási szolgáltatásainak igénybevételére ösztönöznek. A társadalmi hasznok az önvezető autók elterjedéséhez szükséges szakpolitikai döntésekre vannak hatással. A szerző kutatási eredményei szerint a szállítmányozással kapcsolatos munkaerőköltségek éves szinten 90, az üzemanyagköltségek 1,6-2,5 milliárd dollár megtakarítást hozhatnak az önvezető autók használatából fakadóan. A társadalmi hasznokat illetően a balesetek csökkenéséből származó hasznok a becslések szerint éves szinten akár az 500 milliárd dollárt is elérhetik, valamint az üzemanyag-fogyasztás terén évente 13-58 milliárd dollár közötti megtakarítással lehet számolni. Mindösszesen 2018 és 2050 között az önvezető autókból eredő hasznok diszkontált jelenértéke 3,2-6,3 ezer milliárd dollár között mozog.

A Világgazdasági Fórum és a Boston Consulting Group közös publikációjában (WEF-BCG [2018]) szimulációs modell segítségével végez becsléseket az önvezetö autók bevezetése kapcsán. A szimuláció földrajzi területe az egyesült államokbeli Boston (Massachusetts állam). A tanulmány szerint az önvezető autók megjelenése összességében, Boston teljes területére vetítve kedvező lenne, hiszen a mostani állapotokat és a jövőbeli forgatókönyveket figyelembe véve az önvezető autók bevezetésével várhatóan 15 százalékkal visszaesik az autók száma a bostoni utakon, a parkolóhelyeknek fenntartott terület 48 százalékkal csökkenhet, valamint az átlagos utazási idő is 4 százalékkal mérséklődhet. Ugyanakkor a városrészekre szűkítve a szimulációt, eltérö eredményeket kaptak a tanulmány szerzői: a kutatás eredménye szerint Boston belvárosában 5,5 százalékkal nő az átlagos utazással töltött idő, tehát az önvezető autók bevezetése akár forgalmi dugók kialakulásához is hozzájárulhat. Az, hogy az önvezető autók bevezetése mennyire lesz sikeres és egyben kedvező hatású egy adott városban vagy városrészben, számos tényezőtől függ, ilyenek például a jövedelem, a kor, az átlagos menetidö, az átlagos utazás távolsága vagy az adott terület tömegközlekedési hálózatának sürüsége. 
A jelenleg prognosztizálható jelentős előnyök ellenére az önvezető autók társadalmi megítélése nem egységes. Az elmúlt években több olyan nagyszabású nemzetközi kutatás is született, amely alapján nagy bizonyossággal állapíthatunk meg tendenciákat arról, hogy a közvélemény hogyan vélekedik az önvezető autókról. A kutatások nagy része az Egyesült Államokban készült, azonban több tanulmány nemzetközi felmérésekre is épít. A következőkben e felmérések eredményeit mutatjuk be.

\section{Az önvezető autók társadalmi megitélése}

2018 márciusa kiemelten fontos mérföldkő mind az önvezető autók utcai kísérlete, mind a felelősség összetettsége, valamint a társadalmi megítélés fontosságának eszkalálódása szempontjából: egy héten belül két, különböző technológiai alapon működő önvezető autó is halálos baleset résztvevője volt. Az ezt követő társadalmi reakciók intenzívek és szélsőségesen polarizáltak voltak, ${ }^{5}$ rávilágítva arra, hogy a társadalom pontosan érzékeli a téma fontosságát és a mindennapi életre gyakorolt hatását. Annak érdekében, hogy lássuk a társadalmi megítélés időbeli változását és az azt befolyásoló tényezőket, célszerű az önvezető technológiák társadalmi megítélését vizsgáló felméréseket megjelenésük sorrendjében végigvenni.

Schoettle-Sivak [2014] három olyan országban végzett felmérést, amely az önvezető technológiában élen jár: az Egyesült Államokban, az Egyesült Királyságban és Ausztráliában 1533 embert kérdeztek meg. Az eredmények az ő esetükben is kettősek: az emberek többsége pozitív véleményen van az önvezető technológiáról. A válaszadók közel 60 százalékának nagyon pozitív vagy pozitív az általános véleménye az önvezető autókról, 30 százalékuk semleges, és csupán alig több, mint 10 százalékuk vélekedik negatívan. A megkérdezettek nagy elvárásokkal tekintenek az előnyeire: azt várják például, hogy csökkenni fog a balesetek száma, és azok kevésbé súlyosak lesznek, kevesebb lesz a dugó, rövidül az utazási idő, kisebb lesz a környezetterhelés, alacsonyabbak a biztosítási díjak. A válaszadók többsége azonban nagyfokú aggodalmát is kifejezte: a „nagyon aggódom” válaszlehetőséget jelölte meg a válaszadók 46,8 százaléka a rendszerhibából adódó problémák, 34,7 százaléka a felelősségi körök bizonytalansága, 35,2 százaléka a hekkertámadás, 30,2 százaléka az adatbiztonság (helyzet- és desztinációkövetés), 33,5 százaléka a nem önvezető autókkal való interakció, 37 százaléka a gyalogosokkal és kerékpárosokkal való interakció esetén, de aggodalmukat fejezték ki amiatt is, hogy rossz időjárási viszonyok közepette esetleg nem jól müködik a rendszer (28 százalék), és hogy váratlan helyzetekben megzavarodik a rendszer (32,4 százalék).

Kyriakidis és szerzőtársai [2015] felmérésének alapja az önvezető autók témájában készült egyik legnagyobb, 5000 elemü mintán 109 országban végzett felmérésük

\footnotetext{
${ }^{5}$ Az egyik véleménycsoport szerint az önvezető autó „ölt” (az újságcikkek túlnyomó többsége ezt a szót használja), és bizalmi válságról beszél az önvezető technológiákkal szemben. A másik véleménycsoport amellett érvel, hogy az önvezető autók részvételével történt halálos balesetek száma fajlagosan messze alulmúlja a hagyományos autók ugyanezen mutatóit.
} 
feltárta, hogy a válaszadók nagy része nyugtalankodik a szoftvertámadás és a viszszaélések mellett a jogi és biztonsági kérdések miatt is. Továbbá a válaszadók pozitív attitüdjét alapvetően azon lehetőségek határozzák meg, amelyeket az önvezető autóban haladás közben is lehet végezni: e-mailezés, telefonálás, filmnézés, olvasás, pihenés vagy nézelödés. ${ }^{6}$

Platt [2017] és a Calgary Egyetem munkatársai 485 fős mintán vizsgálódtak Kanadában, és olyan szempontokat is figyelembe vettek, amelyeket az előző kutatások nem. Ezek közé tartozik a vezetési stílus, amelynek kapcsán megállapították, hogy az agresszív vezetők igen nagy arányban elutasítják az önvezető autókat. Azok a válaszadók, akik 10-20 órát ülnek autóban hetente, háromszor nagyobb mértékben fogadják el az önvezető autókat, mint akik csak néhány órát autóznak. A gyermekkel rendelkező válaszadók elutasítása háromszor akkora, mint azoké, akik nem nevelnek gyermeket. A válaszadóknak csak 6 százaléka bízna meg minden helyzetben teljes mértékben az önvezető autókban. Több mint 50 százalékuk azonban abban az esetben nagyon szívesen használna önvezető autót, ha még több tesztet végeznének, és a biztonság igazolható lenne. 22,5 százalék válaszolta azt, hogy még ebben az esetben is az utat nézné menet közben, és nem érezné magát biztonságban, ha elfoglalná magát valami más tevékenységgel, ezzel szemben 36 százalékuk olvasna, e-mailezne, filmet nézne, aludna.

Smith-Anderson [2017] 4135 fős mintán vizsgálta az Egyesült Államok felnőtt korú lakosságának véleményét, és szintén megállapították a fent feltárt szélsőséges véleményeket, illetve az elutasítási okok szintén nagyon hasonlók: bizalmatlanság, információhiány, hekkertámadások, biztonság. Kimutatták továbbá, hogy az elfogadottság bizonyos társadalmi csoportokban (férfiak, 45 évnél fiatalabbak, iskolázottabbak) szignifikánsan magasabb - erre a törvényszerüségre Schoettle-Sivak [2016] is rámutatott.

Az AAA [2017] felmérése kutatásunk szempontjából kiemelt jelentőségü, ugyanis olyan időszakban készült, amikor az utcákon az előrehaladott tesztek miatt már reálisan lehet önvezető autókkal találkozni. ${ }^{7}$ A felmérés során 1012 főt kérdeztek meg az Egyesült Államokban, azaz olyan országban, ahol a járókelők már találkozhatnak önvezető autókkal az utcákon. Ennek fényében különösen szembetűnő, hogy azon válaszadók, akik kézzelfogható közelségben érzik az önvezető autókat, 66 százaléka félne, ha bele kellene ülnie, 19 százaléka bízik benne, és 4 százalékuk semleges. Továbbá 54 százalékuk akkor sem érzi magát biztonságban, ha meg kell osztania az útfelületet önvezető autókkal, miközben a válaszadó maga hagyományos autót vezet. 34 százalékuk szerint nincs különbség, 10 százalékuk szerint biztonságosabb lenne a közlekedés, ha önvezető autók is közlekednének, 2 százalékuk

\footnotetext{
${ }^{6}$ E mintával kapcsolatban ugyanakkor hangsúlyozni kell, hogy egy-egy országból csak relatíve kis minta állt rendelkezésre, valamint a 109 ország eltérő gazdasági és kulturális környezetet feltételez.

${ }^{7}$ Néhány példát említve: Arizonában, Phoenix agglomerációjában a Volvo és az Uber, valamint a Google Waymo önvezető autóival találkozhatnak a járókelők. Utóbbi feltűnt már Mountain View (CA), Austin (TX), Kirkland (WA) városban is. A Lyft, a General Motors és az Intel Phoenixben tesztel. Az önvezető autók száma már jelenleg is több száz az Egyesült Államok 48 városának közútjain. Az aktuális lista és térkép megtekinthető: https://avsincities.bloomberg.org.
} 
nem tudja megítélni. Figyelemre méltó ugyanakkor, hogy 59 százalékuk szeretné, ha következő autójában lenne autonóm technológia.

A 2018. márciusi halálos balesetek után három héttel az AAA [2018] megismételte felmérését, ezúttal 1014 főt kérdeztek meg. A bizalmi válság egyértelmüen kimutatható: a 2017-es 63 százalékról 73 százalékra nőtt azoknak a száma, akik félnének egy teljesen önvezető autóval utazni. Továbbá 60 százalékuk akkor sem érzi magát biztonságban, ha meg kell osztania az útfelületet önvezető autókkal, miközben a válaszadó maga hagyományos autót vezet - ez az érték 2017-ben 54 százalék volt.

A kutatásokból tehát egyértelműen megállapítható, hogy a társadalomban van pozitív értelemben vett várakozás az önvezető autók megjelenése iránt, azonban mindezt jelentős aggodalom, nyugtalanság, bizonytalanság övezi. Az is egyértelmü tendencia, hogy ezen aggodalmak kizárólag a teljes mértékben önvezető autókhoz köthetők (a korábban tárgyalt 5. szint), azonban az automatizáltság igen magas szintjét (4. szint) aggodalom nélkül fogadják a válaszadók, ha közben ők maguk kontrollálhatják a folyamatokat. A kutatások többségében előjön az is, hogy a teljes mértékben önvezető autókról kevés a rendelkezésre álló információ, valamint a válaszadók a technológiát még kiforratlannak érzik, és további teszteket tartanak szükségesnek.

\section{Az önvezető autók kockázatai}

Mint minden új technológia bevezetésekor, az önvezető autók esetében is széles skálán tudunk kockázatokat azonosítani, amelyek egy része egyenesen következik az önvezető autók társadalmi megítélésének vizsgálata során feltárt fenntartásokból. E kockázatokat öt nagyobb kategóriába lehet sorolni: 1. TECHNOLÓGIAI, 2. KÖRNYEZETI, 3. IPARÁGI, 4. ETIKAI ÉS 5. KORMÁNYZATI KOCKÁZAT.

1. A teChNolóGIAI JELlegÜ KoCKÁZATON belül kiemelhető az úgynevezett operatív (müködési) kockázat. Az önvezető jármüvek rendkívül komplex eszközökkel és szoftverrel vannak felszerelve, érzékeny szenzorok és összetett algoritmusok felelnek a jármü problémamentes müködéséért. A lehetséges programhibákat vagy meghibásodásokat azonban kockázatként kell azonosítanunk, hiszen ezek komoly hatással lehetnek az önvezető jármüvekre és az adott közlekedési szituáció további résztvevöire is (Yan és szerzötársai [2016], Yeomans [2014]). Baleseti és egészségügyi kockázat is megjelenik, hiszen a közlekedés során utasként vagy járókelöként is szenvedhetünk balesetet, ebből fakadóan pedig (tárgyi vagy személyi) sérülések történhetnek (Yeomans [2014]). Mivel az önvezető autó rendszerei (például GPS, bluetooth, WiFi, $5 \mathrm{G})$ által elektromágneses sugárzásnak is ki vannak téve az utasok, így az önvezető jármüvek tervezésekor ezen egészségügyi szempontokat is figyelembe kell venni (Fleetwood [2017], Trappl [2016]). A technológiával kapcsolatban számtalan biztonsági kockázat is kiemelt tényezővé válik. A digitális technológiák folyamatos terjedésével párhuzamosan ugyanis kiberbiztonsági és adatvédelmi kérdések is felmerülnek. $\mathrm{Az}$ önvezető jármüvek esetében - akár flotta részei, akár magántulajdonban vannak megkerülhetetlen, hogy olyan védelmi technológiákkal legyenek felruházva, amelyek megvédik az utast és környezetét a hekkertámadásokkal (például személyes adatok 
ellopása), a terrortámadásokkal (például ramming) vagy éppen a kiberterrorizmussal (például egy teljes önvezető flotta leállítása) szemben (Schoettle-Sivak [2014], Yan és szerzőtársai [2016], Yeomans [2014]).

2. A technológiai kockázatokhoz szorosan kapcsolódnak a KÖRNYEZETI HATÁsOK is. Az éghajlati kockázat arra hívja fel a figyelmet, hogy az önvezető autók gyártóinak megoldást kell találniuk a szélsőséges vagy a szenzorok hatékonyságát befolyásoló időjárási tényezők (például eső, hóvihar, homokvihar) esetére is, annak érdekében, hogy a jármü e körülmények között is képes legyen biztonságos müködésre (Yeomans [2014]). Emellett az önvezető autóknak fenntarthatósági szempontoknak is meg kell felelniük, tehát tervezésükkor figyelembe kell venni környezetterhelési szempontokat is (Barcham [2014], Schreurs-Steuwer [2016]). Ezek a tényezők természetesen összekapcsolódnak a technológiai és a kormányzati kockázatokkal is.

3. Az IPARÁGI KOCKÁZATOKON belül munkaeröpiaci, gazdasági, bizalmi és fogyasztói kockázat jelenhet meg. Az önvezető autók piaci bevezetése ugyanis minden olyan foglalkozást érinteni fog, melyhez jármüvezető szükséges, mindemellett a változás az autóvezető-tanfolyamokat szervező vállalatokra is kiterjedhet (CGPS [2017]). Csak az Egyesült Államokban több mint 4 millió olyan munkahely van, ${ }^{8}$ amelyek valamilyen vezetéssel kapcsolatos beosztáshoz köthetők, és így nyílt kockázatnak vannak kitéve az önvezető autók potenciális elterjedése által (CGPS [2017]). Újabb kutatások becslései szerint az adott szimulációs forgatókönyv beteljesülésétől függően az egyesült államokbeli munkaerőpiacról 1,3-2,3 millió vezetéshez kapcsolódó munkahely tünhet el 30 év alatt (Groshen és szerzötársai [2018]). További kérdés az, hogy vajon milyen tovagyürüzö gazdasági hatásai lesznek az önvezető jármüvek piaci bevezetésének. Megéri-e majd hosszú távon a vállalatoknak az önvezető autók fejlesztése és karbantartása, megfizethető lesz-e a technológia a fogyasztók számára, mely szektorok lesznek a legkomolyabban érintettek? Mindemellett fontos kérdés még az is, hogy milyen hosszú lesz egy adott önvezetö modell termékéletciklusa (Clements-Kockelman [2017], Winkle [2016]). Ezeket jelentősen befolyásolja a bizalmi kockázat, amely szerint, ha balesetek történnek, vagy hibák merülnek fel az önvezetö technológiák kapcsán, akkor nagyban sérülhet a gyártó vállalat hírneve, illetve a fogyasztók is egyre növekvő fenntartásokkal kezelhetik magát az önvezető technológiát (Yeomans [2014]). A fogyasztók oldaláról további kockázat az, hogy a tesztfázis alatt és a piaci bevezetéskor a technológiának milyen fogadtatása lesz, és milyen ütemben fog elterjedni (Corwin és szerzötársai [2016]).

4. Az azonosított kockázatok közül az egyik leghangsúlyosabb az ETIKAI KOCKÁzAT, hiszen az egyik legfontosabb kérdés, hogy az önvezetö autó rendszere hogyan reagál balesetgyanús szituáció esetén (Blyth és szerzőtársai [2015], Bonnefon és szerzötársai [2016]). ${ }^{9}$ Fontos látni azt, hogy a veszélyhelyzetre nem maga az önvezető autó fog megoldást nyújtani, hanem az önvezető autót müködtetö, emberek által megírt algoritmusok (Bonnefon

\footnotetext{
${ }^{8}$ A tanulmány a 2010-2014 közötti időszak átlagos munkaerőpiaci létszámát veszi alapul.

${ }^{9}$ Analógiaként a trolley problem esete hozható fel. Az alapszituáció a következő: elszabadul egy vonat, amely, ha változatlanul a saját pályáján halad, el fog gázolni öt embert a síneken. Azonban lehetőségünk van arra, hogy a közelünkben lévő váltóval egy másik sínre tereljük a vonatot, viszont ebben az esetben is meghal egy ember. Erkölcsileg melyik döntés meghozatala helyes? Lásd részletesen Foot [1967], Thomson [1985] vagy Holstein [2017] tanulmányát.
} 
és szerzőtársai [2016], Lin [2016], Yeomans [2014]). A megvizsgálandó föbb forgatókönyvek önmagukban is elképesztően bonyolult kérdéseket vetnek fel, egyedi alkotóelemeik pedig szinte végtelen lehetőséget nyújtanak az etikai dilemmák tárgyalására, ami mérnöki, jogi, közgazdasági, filozófiai, informatikai területeket egyaránt érint. E kérdés pedig még hangsúlyosabb abból a szempontból, hogy össztársadalmi szinten képtelenség megegyezésre jutni abban, hogy mi tekinthetö bizonyos (veszély)szituációk kívánatos vagy nemkívánatos kimenetelének (Holstein [2017]).

5. A fenti tényezőket áttekintve belátható, hogy a KORMÁNYZATI KOCKÁzATOK is kiemelt fontosságúak. Egyrészt az önvezető autók világszintü elterjedése esetén a szükséges digitális (például az adatáramlás folyamatosságát és a vezeték nélküli technológiák működését biztosító háttér) és fizikai infrastruktúra (például megfelelő minőségü utak és szükséges városszerkezeti átalakulások) megléte elengedhetetlen (hálózati és infrastrukturális kockázat) (ITF [2015]). Másrészt a kormányoknak az önvezető autók gyártásához és müködtetéséhez kapcsolódó jogokat és kötelezettségek illetően átfogó jogi szabályozásra kell felkészülniük (ITF [2015], Yeomans [2014]), beleértve azt is, hogy egy-egy baleset esetén ki viseli a felelősséget (jogi és szabályozási kockázat).

Egyértelmüen kirajzolódik tehát, hogy komplex kérdéskörrel van dolgunk. Az érem egyik oldalán globális szinten óriási várakozások övezik az önvezető járművek forgalomban történő megjelenését és a köz számára elérhetővé tételét, ugyanakkor automatikusan figyelmet kell szentelnünk a várható pozitívumok és lehetőségek mellett a várható negatívumok és kihívások területének is. Ennek kezelésére adhat választ a felelősségteljes innováció.

\section{A kihívások lehetséges kezelése - a felelősségteljes innováció}

Az önvezető autókra hatalmas várakozással tekintünk, azonban számtalan kérdés felmerül, amit a 2018. márciusi halálos balesetek kiéleztek: az emberek többsége felteszi azt a kérdést, hogy ez biztosan jó lesz-e így, nem veszélyes-e, és milyen hatásai lehetnek a későbbiekben, vajon nem dönti-e romba az emberiséget. Tehát az egészséges várakozás mellett mindenkiben ott munkálkodik a „de”. Így kiemelten fontos, hogy az önvezető autók jövőbeli, nem szándékolt negatív mellékhatásainak csökkentésére és a társadalmi bizalom növelésére jelentős figyelem irányuljon, és ez például úgy müködhet, ha a fejlesztők a felelősségteljes kutatás és innováció (responsible research and innovation, RRI) fogalomkörében munkálkodnak.

\section{A felelösségteljes kutatás és innováció fogalma}

A kutatás és innováció folyamatában a felelősség kérdésköre nem új keletủ fogalom (Genus-Stirling [2018], Stilgoe és szerzőtársai [2013]), azonban a 20. század közepén a felelősség kérdése leginkább csak a társadalommal szemben merült fel. A mai értelemben vett felelösségteljes kutatás és innováció (responsible research and innovation, 
$R R I)$ az Egyesült Államokban jelent meg a 21. század legelején, majd az Európai Unió is átvette néhány évvel később. Mivel az RRI gyökerei a menedzsment- és egyéb tudományos kutatásokban is megtalálhatók (Inzelt-Csonka [2014], Owen és szerzötársai [2012]), így meghatározására több tudományos definíció is született, utalva a koncepció inter- és multidiszciplináris voltára (Buzás-Lukovics [2015], Chorus és szerzötársai [2012], Owen és szerzötársai [2012], Rip [2005], Sutcliffe [2013], TihonIngham [2011]). E definíciók közös pontja a társadalmi felelösség hangsúlyozása, viszont a környezeti és etikai felelősséget eltérő módon emelik ki, és csak néhány meghatározásban jelenik meg a kutatás és innováció nyitottságának és átláthatóságának fontossága (Buzás-Lukovics [2015]).

E sokféleség ellenére azt tapasztaltuk, hogy a tudományos közösségben Schomberg [2011] meghatározása a legelfogadottabb, így kutatásunkban e fogalomra támaszkodunk. Eszerint az RRI „transzparens és interaktív folyamat, amelyben a társadalmi szereplők és az innovátorok kölcsönös felelősséget vállalnak az innovációs folyamat és eredményei etikai elfogadhatósága, fenntarthatósága és társadalmi kívánatossága iránt (annak érdekében, hogy a tudományos és technológiai fejlődés beépülhessen a társadalomba)" (60. o.). Az RRI tehát fontos szerepet szán az innováció szereplői közötti együttműködésnek. ${ }^{10} \mathrm{~A}$ felelősségteljes innováció során nem kizárólag a termékkel kapcsolatos kérdésekre kell választ adni, hanem a kutatási folyamatot és annak céljait érintőket is figyelembe kell venni (Stilgoe és szerzötársai [2013]). Így azon túlmenően, hogy egy-egy új terméknek milyen kockázata és haszna van, valamint milyen egyéb hatások láthatók már elöre, arra is felelnünk kell, hogy a kutatási folyamat során hogyan tudjuk a meglévő standardokat integrálni, hogyan lehet a hatásokat definiálni és mérni, ki a felelős azért, ha valami rosszul sül el, ki ellenőriz, valamint választ kell tudni adni arra is, hogy az adott kutatás mi célt szolgál, ezek a motivációk átláthatók-e, ki fog nyerni az innováción, milyen alternatívák léteznek (Stilgoe és szerzőtársai [2013]).

Annak vizsgálata során, hogy egy kutatás-fejlesztés, innováció (és annak folyamata) felelösségteljes-e, nagyon jó kiindulópontot jelent a felelősségteljes innováció négy dimenziója (Buzás-Lukovics [2015], Carbajo-Cabeza [2018], Owen és szerzőtársai [2012], Stilgoe és szerzőtársai [2013]):

1. Az ELŐRELÁTÁs (anticipation) dimenziója arra utal, hogy a kutatóknak folyamatosan át kell gondolniuk kutatásuk már ismert és egyelöre még nem ismert, de lehetséges veszélyforrásait (azaz nem szándékolt hatásait), azaz a „mi van, ha...?” kérdéseket kell szem előtt tartaniuk. Ezáltal a társadalmi kockázatok jelentős mértékben csökkenthetők.

2. A REFLEXIVITÁst (reflexivity) tekintve a kutató döntéseinek, céljainak, motivációinak lehetséges visszahatásait vizsgáljuk meg, azaz lényegében tükröt tartunk a kutatási folyamat elé.

${ }^{10} \mathrm{E}$ fogalom mellett létezik egy szűkebb meghatározás is az úgynevezett társadalmilag felelős innovációra vonatkozóan, amely kizárólag a társadalmi és etikai megfontolások kutatás-fejlesztési folyamatokba történő integrálását tekinti célnak (Flipse és szerzőtársai [2014]), azonban Batayeh és szerzőtársai [2017] munkájuk során - a beteget középpontba helyező egészségügyi rendszer vizsgálata kapcsán - kitértek arra, hogy a társadalmilag felelős innovációnak tartalmaznia kell a tudományos, a technológiai és a szervezeti innovációt is. 
3. A Bevonás (inclusion) dimenziója a közvetlen érintettek (stakeholders) véleményének meghallgatásán túl a szélesebb nyilvánosság véleményének figyelembevételét jelenti, akár nagyobb, nyílt fórumokon, tanácskozásokon keresztül.

4. ReAGÁLÁs (responsiveness), amely az elöző pontokkal szoros kapcsolatban van, hiszen a felelösségteljes innováció azt igényli, hogy a kutatónak legyen lehetősége a véleményekre, a felismert kockázatokra, veszélyforrásokra reagálni, és ezek szerint megváltoztatni kutatása irányát.

Az Európai Bizottság e dimenziókkal átfedésben a felelősségteljes innováció hat kulcselemét (RRI keys) fogalmazta meg (EC [2014]), amelyek már sokkal inkább az RRI gyakorlati bevezetése felé terelik a folyamatot.

1. A társadalom bevonása az innovációs folyamatokba • Ezáltal lehet biztosítani a létrejövő outputok szélesebb körü elfogadottságát és a társadalom sürgető problémáinak hatékonyabb megoldását. Ez lényegében a fentebb említett BEvoNÁs dimenziónak felel meg.

2. NemeK кÖzÖtTI EgYeNLŐsÉG • Célja a nők esélyeinek növelése, valamint a női kutatók alulreprezentáltságának javítása, mely az ELÖRELÁTÁs és a REAGÁLÁs dimenzióval van szoros kapcsolatban.

3. Tudományos Nevelés • Célja a jövő kutatói és a társadalom más szereplöi tudásának bővítése, hogy az innovációs folyamatokban teljesen és aktívan részt tudjanak venni (az első kulcselem teljesülése érdekében is). Emellett fontos a fiatalok körében a kreativitás minél korábbi kibontakoztatása, a természettudományok iránti kíváncsiság felkeltése és fenntartása. Ez szintén az RRI BEvonÁs dimenzióját erősíti, de hozzájárulhat a REFLEXIVITÁs dimenziójához is.

4. Eтіка • Az Európai Unió által megfogalmazott közös értékek (alapvető emberi jogok és etikai standardok) figyelembevétele és betartása elsődleges szempont a felelősségteljes innováció folyamatában, mely mind az ELŐRELÁTÁs, mind a REAGÁLÁs dimenzióját erősíti.

5. Nyílt HOZzÁfÉRÉs • Mindenki számára biztosítani kell a kutatási eredmények elérhetőségét. Ennek következtében érvényesülhet az érdekeltek, a szakértők és a társadalom tagjainak az innovációs folyamatokba történő szélesebb körü BEvONÁsA (amely az RRI első dimenziója).

6. IRÁNYÍTÁs • A szabályozási környezet nagy hatással lehet az innovációs folyamatok végkimenetelére, az outputok alakulására; leginkább az RRI REFLEXIVITÁs és REAGÁLÁs dimenzióját támogatja.

E hat kulcselem megfogalmazásával tehát az RRI gyakorlati alkalmazására helyezödött a hangsúly, és az Európai Unió is arra törekszik, hogy a kutatóintézetek napi müködésébe integrálja az RRI-t (Arnaldi és szerzötársai [2015], Forsberg és szerzőtársai [2015]). Az RRI gyakorlati bevezetésével kapcsolatosan a szakirodalom többféle szakterületét meg lehet találni, amelyek az akadémiai környezetben történő elemzéseken (például Fisher [2007], Lukovics és szerzötársai [2017]) túl leginkább az egészségügyi szektort (például Antiel-Flake [2017], Batayeh és szerzőtársai [2017], Kerr és szerzőtársai [2017]), a bio- és nanotechnológiát (például 
Flipse és szerzőtársai [2014], Garden és szerzőtársai [2016]) és a robotikát (például Stahl-Coeckelbergh [2016]) érintik. Arra vonatkozóan azonban kutatásunk során nem találtunk elemzést, hogy egy konkrét (radikális) innováció esetén, amely már a tesztfázisában van, hogyan lehetne a felelősségteljes innováció gondolatkörét integrálni. Ezáltal az önvezető autó mint radikális innováció kiváló példa, így a következőkben azt vizsgáljuk meg, hogy az önvezető autó kifejlesztése hogyan lehet felelősségteljes innováció. Ehhez az RRI kulcselemeit és dimenzióit használjuk keretként, és azt vizsgáljuk, hogy az önvezető autó és a feltárt kihívások, kockázatok hogyan kezelhetők ezen elemek alapján.

\section{A felelösségteljes innováció válaszai az önvezető autók kihívásaira}

A teljes mértékben önvezetö autók (automatizáció 5. szINTJE) jelen pillanatban olyan innovációs outputként definiálhatók, amelyek az előrejelzések szerint az emberiség szempontjából kiemelt jelentőségüek, és komoly változásokhoz vezethetnek. Továbbá az önvezető autókkal kapcsolatban jelen lévő bizonytalanság és információhiány a társadalom tagjaiban szélsőséges (pozitív és negatív) véleményeket szül. Mindezt kiélezte a 2018. márciusi két halálos baleset, és világosan megmutatta: a társadalom bizalma kulcskérdés az önvezetőautó-projektek sikeressége szempontjából. A technológiai fejlesztések mellett tehát társadalomtudományi lépések megtételére is szükség van. Mindezek olyan peremfeltételeket alakítanak ki, amelyek tapasztalataink szerint eredményesen kezelhetők akkor, ha az önvezető autók innovációja a felelősségteljes innováció keretrendszerében zajlik, csökkentve az esetleges nem szándékolt jövőbeli negatív mellékhatások valószínűségét.

A korábbiakban bemutatott, az önvezető autókat érintő konkrét kihívások megoldását, feloldását az RRI kulcselemei és dimenziói alapján is felépíthetjük (2. táblá$z a t)$. Jól kitünik, hogy egy-egy kihívás kezelése több kulcselemet és dimenziót is érint. Például az önvezető autókkal szembeni társadalmi megosztottságot mint kihívást az RRI kulcselemei közül a társadalom bevonásával és tájékoztatásával, a tudományos neveléssel vagy akár a kutatási eredmények nyilt hozzáférésével is feloldhatjuk. A dimenziók esetében pedig az ELŐRELÁTÁs, a BEVONÁs és a REFLEXIVITÁs játszik szerepet e kihívás esetén. Mindez azt is mutatja, hogy amennyiben a kutatás-fejlesztési és innovációs tevékenységet felelősségteljesen kívánjuk megvalósítani, akkor az komplex szemléletmódot és komplex eszköztárat igényel, amelyben az említett interdiszciplináris megközelítésnek is kiemelt szerepe van.

A 2. táblázatban szereplő kulcselemek és dimenziók azonosítása alapján már konkrét lépéseket is tudunk javasolni annak érdekében, hogy az önvezető autók bevezetésével kapcsolatos kihívások jelentős részét kezelni lehessen a felelősségteljes innováció szempontrendszerének segítségével. E javaslatok a következök.

1. A felelősségteljes innováció gyakorlati alkalmazása szempontjából kiemelten fontos tényezőként kell tekintenünk a kutatók és innovátorok napi szintü $K+F+I$ döntéseire. Fontos, hogy nemcsak stratégiai jellegü, nagy volumenü döntéseket sorolunk ide, hanem minden apró, olykor jelentéktelennek tünő döntést is, amelyeket a kutatók 


\section{2. táblázat}

Az önvezető autók kihívásainak RRI-kulcselemei és -dimenziói

\begin{tabular}{llll}
\hline Az önvezető autó kihívásai & \multicolumn{1}{c}{ RRI-kulcselem } & \multicolumn{1}{c}{ Dimenzió } & \multicolumn{1}{c}{ Javasolt beavatkozás } \\
\hline - Társadalmi megosztottság & 1. A társadalom & 1. ELőreLÁTás & - Társadalmi \\
- Információ- és bizalomhiány & bevonása & 2. BEVonás & szempontok \\
az 5. szInTư automatizálással & 2. Nemek közötti & 3. REFLEXIVITÁs & figyelembevétele \\
szemben & egyenlőség & & az innovátorok napi \\
- Félelem, hogy kiforratlan & 3. Tudományos & K + F + I döntései \\
a technológia, és az időjárás & nevelés & során \\
befolyásolja & 5. Nyílt hozzáférés & - Magas fokú \\
- Közép- és hosszú & & transzparencia \\
távú társadalmi hatások & & és tájékoztatás \\
bizonytalansága & &
\end{tabular}

- Közép- és hosszú távú környezeti hatások bizonytalansága

- Rendszerhibából adódó problémák - Hekkertámadás, adatbiztonság

1. A társadalom
bevonása
4. Etika

1. ELŐRELÁTÁs

2. BEVONÁS

3. REFLEXIVITÁs
Környezeti szempontok figyelembevétele

az innovátorok napi $\mathrm{K}+\mathrm{F}+\mathrm{I}$ döntései során
1. A társadalom bevonása
2. Nemek közötti egyenlőség
4. Etika
5. Nyílt hozzáférés
6. Irányítás
1. ElőRELÁtás - Magas fokú
2. BEVONÁs transzparencia
3. RefLEXIVITÁs és tájékoztatás
- Érdekeltek bevonása

\begin{tabular}{|c|c|c|c|}
\hline $\begin{array}{l}\text { - Közlekedés egyéb szereplőivel } \\
\text { való interakció hatásai } \\
\text { - Az autók „döntései” } \\
\text { vészhelyzetben } \\
\text { - Közép- és hosszú távú etikai } \\
\text { hatásainak bizonytalansága }\end{array}$ & 4. Etika & $\begin{array}{l}\text { 1. ELŐRELÁTÁs } \\
\text { 2. BEVONÁS } \\
\text { 3. REFLEXIVITÁS }\end{array}$ & $\begin{array}{l}\text { Etikai szempontok } \\
\text { figyelembevétele } \\
\text { az innovátorok napi } \\
\mathrm{K}+\mathrm{F}+\mathrm{I} \text { döntései } \\
\text { során }\end{array}$ \\
\hline $\begin{array}{l}\text { - Szabályozási környezet } \\
\text { kiforratlansága } \\
\text { - Felelősségi körök } \\
\text { bizonytalansága }\end{array}$ & 6. Irányítás & 4. REAGÁLÁs & Kormányzás, irányítás \\
\hline
\end{tabular}

Forrás: saját szerkesztés.

$\mathrm{K}+\mathrm{F}+\mathrm{I}$ munkájuk során hoznak. ${ }^{11} \mathrm{~A}$ kihívást a döntések során az okozza, hogy az önvezető autók $\mathrm{K}+\mathrm{F}+\mathrm{I}$ tevékenységében jellemzően müszaki-természettudományos gondolkodású emberek hoznak olyan müszaki-természettudományos döntéseket, amelyeknek - a fentebb leírtak miatt - az átlagosnál jóval nagyobb, a műszaki-természettudományi körön jelentősen túlmutató hatásai vannak. A műszaki-természettudományi

\footnotetext{
${ }^{11}$ Itt kell megjegyezzük, hogy tapasztalataink szerint a gyakorlati kutatók sok esetben - igen meglepő módon - nincsenek tisztában azzal, hogy ők munkájuk során valójában döntéseket hoznak (Lukovics-Fisher [2017]).
} 
gondolkodású döntéshozók értelemszerüen úgy szocializálódtak, hogy kiváló műszakitermészettudományi döntéseket tudnak hozni, azonban esetünkben nagyon fontos az is, hogy a döntés pillanatában társadalmi, etikai, környezeti szempontokat is figyelembe vegyenek, hiszen döntéseik csak így közelíthetnek a felelősségteljes innováció kritériumrendszeréhez (lásd a fent leírt interdiszciplináris megközelítést). Tehát a döntéshozók oldaláról társadalomtudományi integráció szükséges, amelynek többféle lehetséges módszere ismert, az egyik legelfogadottabb az úgynevezett integrált társadalom- és természettudományi kutatás (Socio-Technical Integration Research, STIR). ${ }^{12}$

2. Tekintettel arra, hogy minden civilizációban élő ember életét befolyásoló radikális innovációról van szó, kiemelten nagy hangsúlyt kell fektetni a transzparenciára és a lakosság folyamatos és pontos tájékoztatására. Mivel a tájékoztatni kívánt lakosság szélsőségesen heterogén, így igen széles skálán mozog, hogy mely kommunikációs csatornát fogyasztják. Ezt a tényt a kommunikációs stratégia megtervezésekor figyelembe kell venni, ügyelve arra, hogy az önvezető autók legfőbb ellenzői az idősebb, mérsékelt online jelenléttel jellemezhetô rétegből kerülnek ki.

3. Minden érdekelt igényeinek és elképzeléseinek korai megértése és beépitése kiemelten fontos, és ez megteremti az alapját annak, hogy a legfontosabb értékek (például fenntarthatóság, biztonság, etika, átláthatóság stb.) optimális egyensúlya már a tervezési fázisban elérhető legyen. Mivel a hasonló radikális innovációk esetén felmerülö nehéz kérdések természetes velejárója a társadalmi aggodalom, ezek felelősségének korai szakaszban történő felvállalása elengedhetetlen.

4. A fenti három lépés elsősorban alulról felfelé (bottom-up) építkező szemléletmódot tükröz, azonban véleményünk szerint fontos a felülről lefelé (top-down) építkező szemlélet is, azaz egy olyan szabályozói környezet kialakitása, amely elöírja a felelösségteljes innováció elemeinek (például társadalmi, etikai, környezeti hatások) figyelembevételét, valamint lehetőséget teremt a többszöri visszacsatolásra is (elöírja), hogy a kutatás-fejlesztési és innovációs folyamatok valóban társadalmilag hasznos outputokat eredményezzenek. A szabályozás azért is fontos, mert az önvezető technológiák elterjedése vonzóbbá, kényelmesebbé (és hosszú távon olcsóbbá) teszi az autóhasználatot, így a piaci logika és az autóipari vállalatok érdeke a még több autóhasználat felé terelheti az embereket. Amenynyiben ez bekövetkezik, akkor jelentős mértékben súlyosbítják - többek között - a városi közlekedési problémákat. Éppen ezért fontos, hogy azönvezető jármüvek elterjedését tudatos, globális, országos és helyi szintü tervezés és szigorú szabályozás elözze meg és kísérje.

A fentiek alapján kitünik, hogy annak érdekében, hogy a felelősségteljes innováció érvényesüljön, két fontos szempontot kell figyelembe venni, és ezek egyben a sikeres beavatkozások alapjai is lehetnek:

- interdiszciplináris megközelítés, amely során mérnököknek, társadalomtudósoknak, szakpolitikusoknak és az érdekelteknek együtt kell müködniük a technológiai fejlesztés jövőbeli irányainak meghatározásában;

${ }^{12}$ A módszer lényege, hogy a műszaki-természettudományi gondolkodású emberek látóköre kiegészül a különböző társadalomtudományi (szociológiai, közgazdasági, környezeti, etikai, filozófiai stb.) szempontokkal (Fisher [2007], Lukovics-Fisher [2017]). 
- elörelátó elemzés már a technológiai tervezés korai szakaszában, hiszen ekkor még több tervezési lehetőség áll rendelkezésre, így a technológiai fejlesztés még viszonylag könnyen módosítható.

E tényezők az RRI dimenziói közül leginkább a BEVONÁs, az ELŐRELÁTÁs és a REFLEXIVITÁs területét érintik. Ugyanakkor e tényezők az RRI gyakorlati bevezetésének kizárólag szükséges, de nem elégséges feltételei, hiszen a REAGÁLÁs dimenziója, azaz a megfelelő (és kellően átfogó) szabályozói környezet kialakítása is legalább ugyanolyan fontos, hiszen e nélkül a másik három dimenzió sem képes megfelelően müködni.

Fontos hangsúlyoznunk, hogy a felelősségteljes innováció keretrendszerének alkalmazása nem csodaszer, így értelemszerủen nem lesz képes arra, hogy minden felmerülő kihívást automatikusan kezeljen. Arra viszont igen, hogy ha úgy hajtjuk végre a javasolt lépéseket - támaszkodva az interdiszciplináris megközelítés és a proaktív szemlélet (szükséges, de nem elégséges) feltételeire -, hogy minden érintett aktívan vesz részt a folyamatokban (és nem csak passzívan szemléli), akkor a rendszer képes lesz hatékonyan kezelni a kihívások jelentős részét (2. ábra).

\section{2. ábra}

Az önvezető autók és a felelősségteljes innováció logikai keretrendszere

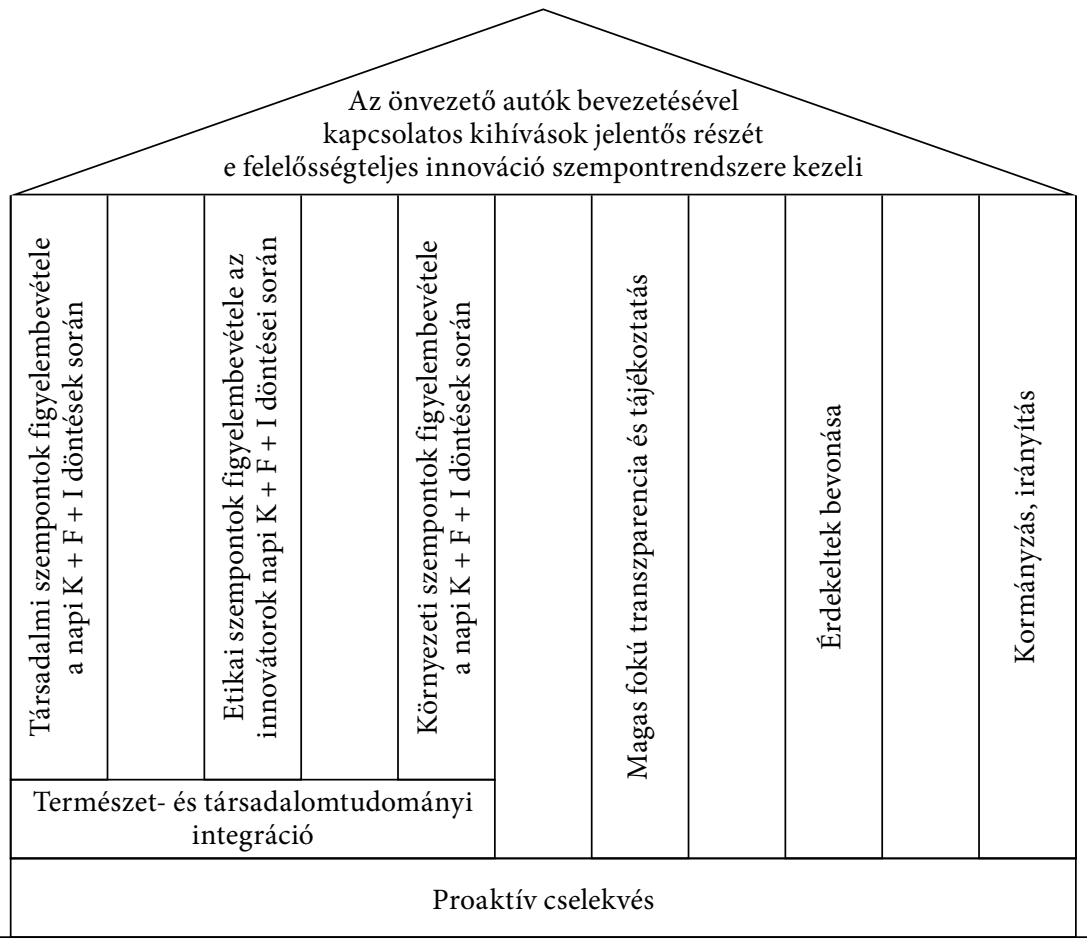

Interdiszciplináris megközelítés

Forrás: saját szerkesztés. 
A konkrét lépéseket mielőbb el kell kezdeni, hiszen a hatások eléréséhez idő kell. Ezek az önvezető autók bevezetésével kapcsolatos innovációmenedzsment mindhárom szintjét (STRATÉGIAI, OPERÁCIÓs, TAKTIKAI) érintik, amelyek más-más kihívásokat képesek kezelni (Santoni de Sio [2016]):

1. STRATÉGIAI SZINT • az automata vezetési rendszerek tágan értelmezett társadalmi hatásai hogyan láthatók előre, hogyan irányíthatók és/vagy szabályozhatók;

2. OPERÁCIÓs SZINT • az automata járműveket hogyan kellene programozni, hogy megfelelően „reagáljanak” különböző környezetben;

3. тAкTIKAI SZINT • a közúti közlekedést hogyan kellene szabályozni, hogy az automata és a hagyományos jármüvek is megférjenek egymás mellett?

\section{Összegzés}

Az önvezető autók fejlesztése jóval elörébb tart, mint ahogy azt a széles közvélemény gondolja: 73 város lakói napi életvitelük során, városuk forgalmában találkozhatnak önvezető autókkal, sőt utazhatnak is bennük az utolsó fázisú tesztek résztvevőiként. Az előrejelzések sok esetben extrém változásokat jósolnak az önvezető autók által az átlagember mindennapjaira gyakorolt lehetséges változásokat vizsgálva.

Ugyanakkor számtalan kérdésre nincs még megnyugtató válasz, és több olyan kockázat is fennáll, amely az önvezető autók megítélését sok esetben negatív irányba befolyásolja. Mindezek tapasztalataink szerint eredményesen kezelhetők akkor, ha az önvezető autók fejlesztése a felelősségteljes innováció keretei között zajlik, csökkentve az esetleges nem szándékolt jövőbeli negatív mellékhatások valószínűségét. Az önvezető autók fejlesztése olyan mértékű radikális innovációnak tekinthető, ahol a felelősségteljes innováció fogalomkörének soha nem látott mértékủ jelentősége van.

A felelösségteljes innováció dimenziói és kulcselemei olyan keretrendszert jelölnek ki, amelyben megadhatók azok a konkrét cselekvések, amelyek betartása segíthet a kockázatok csökkentésében és a nyitott kérdésekre adott megnyugtató válaszok megtalálásában. A felelősségteljes innováció gyakorlati alkalmazása szempontjából kiemelten fontos tényezőként kell tekintenünk a kutatók és innovátorok napi szintű $\mathrm{K}+\mathrm{F}+\mathrm{I}$ döntéseire, kiemelten azokra a társadalmi, etikai, környezeti kérdésekre, amelyeknek a megválaszolása természet- és társadalomtudományi integrációval hatékonyan elősegíthető. Szintén nagy hangsúlyt kell fektetni a transzparenciára és lakosság folyamatos és pontos tájékoztatására, az érdekeltek igényeinek és elképzeléseinek korai megértésére és beépítésére, a szabályozási környezet kialakítására. Mindezek szükséges, de nem elégséges feltétele az interdiszciplináris megközelítés és a proaktivitás.

Kiemeljük, hogy a felelősségteljes innováció keretrendszerének alkalmazása nem képes minden felmerülő kihívás automatikusan kezelésére. Arra viszont igen, hogy ha a javasolt lépéseket minden érintett aktív részvételével hajtjuk végre, akkor a felelősségteljes innováció keretrendszere a kihívások jelentős részét képes lesz hatékonyan kezelni. 


\section{Hivatkozások}

AAA [2017]: Vehicle Technology Survey. Automotive Engineering, Washington.

AAA [2018]: Vehicle Technology Survey - Phase IIIB. Automotive Engineering, Washington.

Antiel, R. M.-Flake, A. W. [2017]: Responsible surgical innovation and research in maternalfetal surgery. Seminars in Fetal and Neonatal Medicine, Vol. 22. No. 6. 423-427. o. https:// doi.org/10.1016/j.siny.2017.05.002.

Arbib, J.-SebA, T. [2017]: Rethinking Transportation 2020-2030: The Disruption of Transportation and the Collapse of the Internal Combustion Vehicle and Oil Industries. A RethinkX Sector Disruption Report, május. https://static1.squarespace.com/static/ 585c3439be65942f022bbf9b/t/591a2e4be6f2e1c13df930c5/1494888038959/RethinkX+ Report_051517.pdf.

Arnaldi, S.-Quaglio, G.-Ladikas, M.-O'Kane, H.-Karapiperis, T.-Srinivas, K. R.Zнао, Y. [2015]: Responsible governance in science and technology policy: Reflections from Europe, China and India. Technology in Society, Vol. 42. 81-92. o. http://dx.doi. org/10.1016/j.techsoc.2015.03.006.

BARcham, R. [2014]: Climate and Energy Impacts of Automated Vehicles. Goldman School of Public Policy, University of California, Berkeley, CA.

Batayeh, B. G.-Artzberger, G. H.-Williams, L. D. A. [2017]: Socially responsible innovation in health care: Cycles of actualization. Technology in Society, sajtó alatt, https://doi. org/10.1016/j.techsoc.2017.11.002.

Blanchet, M.-Rinn, T. [2016]: The Industrie 4.0 Transition Quantified: How the Fourth Industrial Revolution is Reshuffling the Economic, Social and Industrial Model. Roland Berger Publications, München.

BLix, M. [2015]: The Economy and Digitalization: Opportunities and Challenges. Confederation of Swedish Enterprise, Stockholm, http://www.martenblix.com/uploads/ 6/2/7/2/62723607/blix_digitalization_report_20160207.pdf.

BLM [2015]: Emerging Risks. Driverless Cars. Driving Redefined. BLM LLP.

Blyth, P. L.-Mladenovic, M. N.-Nardi, B. A.-Su, N. M.-Ekbia, H. R. [2015]: Driving the Self-driving Vehicle: Expanding the Technological Design Horizon. IEEE International Symposium on Technology and Society (ISTAS), Dublin.

Bonnefon, J. F.-Shariff, A.-Rahwan, I. [2016]: The Social Dilemma of Autonomous Vehicles. Science, Vol. 352. No. 6293. 1573-1576. o. https://doi.org/10.1126/science.aaf2654.

BuzÁs Norbert-Lukovics Miklós [2015]: A felelősségteljes innovációról. Közgazdasági Szemle, 62. évf. 4. sz. 438-456. o. http://www.kszemle.hu/tartalom/letoltes.php?id=1548.

CAPGemini [2011]: The Challenges of the Digital Revolution. Digital Transformation Review, No. 1. Capgemini Consulting.

CARbajo, R.-Cabeza, L. F. [2018]: Renewable energy research and technologies through responsible research and innovation looking glass: Reflexions, theoretical approaches and contemporary discourses. Applied Energy, Vol. 211. 792-808. o. https://doi.org/10.1016/j. apenergy.2017.11.088.

CGPS [2017]: Stick Shift: Autonomous Vehicles, Driving Jobs, and the Future of Work. Center for Global Policy Solutions, Washington, DC.

Chorus, C.-van Wee, B.-Zwart, S. [2012]: TPM Catalogue: Concepts, Theories, Methods. Delft University of Technology, Delft.

Clements, L. M.-Kockelman, K. M. [2017]: Economic Effectst of Automated Vehicles. Transportation Research Record: Journal of the Transportation Research Board, Vol. 2606. No. 1. 1-19. o. https://doi.org/10.3141/2606-14. 
Corwin, S.-Jameson, N.-Pankratz, D. M.-Willigmann, P. [2016]: The Future of Mobility: What's Next? Tomorrow's Mobility Ecosystem - and How to Succeed in It. Deloitte University Press, https://www2.deloitte.com/insights/us/en/focus/future-of-mobility/roadmapfor-future-of-urban-mobility.html.

Davies, R. [2015]: Industry 4.0: Digitalisation for Productivity and Growth. Briefing. European Parliamentary Research Service. European Parliament, Brüsszel.

EC [2014]: Responsible Research and Innovation: Europe's ability to respond to societal challenges. European Commission, Brüsszel, https://ec.europa.eu/research/swafs/pdf/pub_rri/ KI0214595ENC.pdf.

FISHER, E. [2007]: Integrating Science and Society in the Laboratory: Center for Integrated Nanotechnologies. Los Alamos National Laboratory, Los Alamos, NM.

Fleetwood, J. [2017]: Public Health, Ethics, and Autonomous Vehicles. American Journal of Public Health, Vol. 107. 532-537. o. https://doi.org/10.2105/AJPH.2016.303628.

Flipse, S. M.-van der Sanden, M. C. A. -Radstake, M.-de Winde, J. H.-Osseweijer, P. [2014]: The DNA of socially responsible innovation. EMBO reports, No. 15. 134-137. o. https://doi.org/10.1002/embr.201337949.

Foот, P. [1967]: The Problem of Abortion and the Doctrine of Double Effect. Oxford Review, No. 5. 5-15. o. https://doi.org/10.1093/0199252866.003.0002.

Forsberg, E.-M.-Quaglio, G.-O'Kane, H.-Karapiperis, T.-Woensel, L. vonARnALDI, S. [2015]: Assessment of science and technologies: Advising for and with responsibility. Technology in Society, Vol. 42. 21-27. o. http://dx.doi.org/10.1016/j.techsoc. 2014.12.004.

Garden, H.-Bowman, D. M.-Haesler, D.-Winickoff, D. E. [2016]: Neurotechnology and Society: Strengthening Responsible Innovation in Brain Science. Neuron, Vol. 92. No. 3. 642-646. o. https://doi.org/10.1016/j.neuron.2016.10.053.

Genus, A.-Stirling, A. [2018]: Collingridge and the dilemma of control: Towards responsible and accountable innovation. Research Policy, Vol. 47. No. 1. 61-69. o. https:// doi.org/10.1016/j.respol.2017.09.012.

Giffi, C.-Vitale, J.-Robinson, R.-Pingitore, G. [2017]: The Race to Autonomous Driving: Winning American Consumers' Trust. Deloitte Review, No. 20. 73-93. o.

Glancy, D. J. [2015]: Autonomous and Automated and Connected Cars-Oh My! First Generation Autonomous Cars in the Legal Ecosystem. Minnesota Journal of Law, Science \& Technology, Vol. 16. No. 2. 619-691. o.

Groshen, E. L.-Helper, S.-MacDuffie, J. P.-Carson, C. [2018]: Preparing U. S. Workers and Employers for an Autonomous Vehicle Future. Study Prepared for Securing America's Future Energy, Washington, DC.

Holstein, T. [2017]: The Misconception of Ethical Dilemmas in Self-driving Cars. Megjelent: Dodig-Crnkovic, G. (szerk.): Proceedings of the Summit of the International Society for the Study of Information on Digitalisation for a Sustainable Society: Embodied, Embedded, Networked, Empowered through Information, Computation \& Cognition. június 12-16. Göteborg.

Hwang, J. S. [2016]: The Fourth Industrial Revolution (Industry 4.0): Intelligent Manufacturing. Researchgate Publications, SMT Prospects \& Perspectives, http://www.jenniehwang. com/pdfs/industry4.pdf.

Inzelt Annamária-Csonka László [2014]: Responsible Science in Societies Megjelent: Buzás Norbert-Lukovics Miklós (szerk.): Responsible innovation. University of Szeged, Szeged, 57-72. o. 
ITF [2015]: Automated and Autonomous Driving: Regulation under Uncertainty. International Transport Forum Policy Papers, No. 7. OECD Publishing, Párizs, https://doi. org/10.1787/5jlwvzdfk640-en.

Kagermann, H.-Anderl, R.-Gausemeier, J.-Schuh, G.-Wahlster, W. [2016]: Industrie 4.0 in a Global Context: Strategies for Cooperating with International Partners. Acatech Study. Herbert Utz Verlag, München, https://www.acatech.de/wp-content/ uploads/2018/03/acatech_STU_engl_KF_Industry40_Global.pdf.

Keeney, T. [2017]: Mobility-As-A-Service: Why Self-driving Cars Could Change Everything. Research White Paper, ARK Invest, New York, https://research.ark-invest.com/hubfs/1_ Download_Files_ARK-Invest/White_Papers/Self-Driving-Cars_ARK-Invest-WP.pdf.

KERR, A.-HILl, R. L.-Till, C. [2017]: The limits of responsible innovation: Exploring care, vulnerability and precision medicine. Technology in Society, sajtó alatt, https://doi. org/10.1016/j.techsoc.2017.03.004.

Klitou, D.-Conrads, J.-Rasmussen, M.-Probst, L.-Pedersen, B. [2017]: Germany: Industrie 4.0. European Commission, Brüsszel.

Kovács Olivér [2017a]: Az ipar 4.0 komplexitása - I. Közgazdasági Szemle, 64. évf. 7-8. sz. 823-851. o. https://doi.org/10.18414/ksz.2017.7-8.823.

Kovács Olivér [2017b]: Az ipar 4.0 komplexitása - II. Közgazdasági Szemle, 64. évf. 9. sz. 970-987. o. https://doi.org/10.18414/ksz.2017.9.970.

Krishna, S. [2017]: Enhancing Academic Outcome Through Digitalization. Conference paper, Quality Enrichment and Excellence in Indian Higher Education System in the Era of Globalization, Csennai.

Kuruczleki Éva-Pelle Anita-Laczi Renáta-Fekete Boglárka [2016]: Doing Business in the EU under the fourth industrial revolution. Challenges ahead of knowledge-intensive economic actors. Megjelent: Dermol, V.-Trunk, A.-Smrkolj, M. (szerk.): Managing Innovation and Diversity in Knowledge Society Through Turbulent Time: Proceeding MakeLearn and TIIM Joint International Conference, Temesvár.

Kyriakidis, M.-Happee, R.-De Winter J. C. F. [2015]: Public opinion on automated driving: Results of an international questionnaire among 5000 respondents. Transportation Research, Part F. Vol. 32. 127-140. o. https://doi.org/10.1016/j.trf.2015.04.014.

Lengyel ImRe-Szakálné Kanó Izabella-Vas Zsófia-Lengyel Balázs [2016]: Az újraiparosodás térbeli kérdőjelei Magyarországon. Közgazdasági Szemle, 63. évf. 6. sz. 615-646. o. https://doi.org/10.18414/KSZ.2016.6.615.

Lin, P. [2016]: Why Ethics Matters for Autonomous Cars. Megjelent: Maurer, M.-Gerdes, J. C.Lenz, B.-Winner, H. (szerk.): Autonomous Driving: Technical, Legal and Social Aspects. SpringerOpen, 69-85. o. https://doi.org/10.1007/978-3-662-48847-8_4.

Litaman, T. [2017]: Autonomous Vehicle Implementation Predictions: Implications for Transport Planning. Victoria Transport Policy Institut, https://www.vtpi.org/avip.pdf.

Lukovics Miklós-Udvari Beáta-Nádas Nikoletta [2017]: A felelősségteljes innováció és a jövő kutatógenerációja. Vezetéstudomány, 48. évf. 8-9. sz. 89-100. o. https://doi. org/10.14267/veztud.2017.09.09.

Lukovics, M.-Fisher, E. [2017]: Socio-Technical Integration Research in an EasternEuropean Setting: Distinct Features, Challenges and Opportunities. Society \& Economy, Vol. 39. No. 4. 501-528. o. https://doi.org/10.1556/204.2017.004.

Magruk, A. [2016]: Uncertainty in the Sphere of the Industry 4.0: Potential Areas to Research. Business, Management and Education, Vol. 14. No. 2. 275-291. o. https://doi.org/10.3846/ bme.2016.332. 
Manyika, J.-Lund, S.-Bughin, J.-Woetzel, J.-Stamenov, K.-DhingRa, D. [2016]: Digital Globalization: The New Era of Global Flows. McKinsey Global Institute, New York.

Montgomery, W. D. [2018]: Public and Private Benefist of Autonomous Vehicles. Study Prepared for Securing America's Future Energy, Washington, DC.

Nagy Benedek-Lengyel Imre [2016]: The Structural Change of Manufacturing in Hungary, 2008-2014. Külgazdaság, különszám, 2. évf. 2. sz. 3-27. o.

NAGy Judit [2017]: Az ipar 4.0 fogalma, összetevői és hatása az értékláncra. Műhelytanulmány, 167. sz. Budapesti Corvinus Egyetem, Vállalatgazdaságtan Intézet, Budapest.

OECD [2017a]: Making Globalization Work: Better Lives for All. OECD Publishing, Párizs. OECD [2017b]: Key Issues for Digital Transformation in the G20. OECD Publishing, Párizs. OW [2014]: Digital Revolution: New Customer Experiences, New Business Models, New Transformations. Oliver Wyman, March and McLennan Companies, https://www.oliverwyman. com/content/dam/oliver-wyman/global/en/2016/jan/Oliver\%20Wyman\%20_\%20Digital $\% 20$ Revolution.pdf.

Owen, R.-Macnaghten, P.-Stilgoe, J. [2012]: Responsible research and innovation: From science in society to science for society, with society. Science and Public Policy, Vol. 39. No. 6. 751-760. o. https://doi.org/10.1093/scipol/scs093.

Pfohl, H. C.-YAhsi, B.-Kurnaz, T. [2015]: The Impact of Industry 4.0 on the Supply Chain. Megjelent: Kersten, W.-Blecker, T.-Ringle, C. M. (szerk.): Innovations and Strategies for Logistics and Supply Chains: Technologies, Business Models and Risk Management. Proceedings of the Hamburg International Conference of Logistics (HICL).

Platt, M. [2017]: Drivers cautious but curious over automated cars: First Canadian study shows. University of Calgary, Calgary.

Prisecaru, P. [2016]: Challenges of the fourth industrial revolution. Knowledge HorizonsEconomics, Vol. 8. No. 1. 57-62. o.

RiP, A. [2005]: Technology Assessment as Part of the Co-Evolution of Nanotechnology and Society: The Thrust of the TA Programme in NanoNed. Conference on Nanotechnology in Science, Economy and Society, Marburg.

Santoni De Sio, F. [2016]: White paper on the Ethics of Self-driving Cars for the Dutch Ministry of Infrastructure and Environment. Delft University of Technology, Delft.

Schmidt, R.-Möhring, M.-Härting, R. C.-Reichstein, C.-Neumaier, P.-Jozinovic, P. [2015]: Industry 4.0-Potentials for Creating Smart Products: Empirical Research Results. Megjelent: Abramowicz, W. (szerk.): Business Information Systems. $18^{\text {th }}$ International Conference, BIS 2015. Poznan, 16-27. o.

Schoettle, B.-Sivak, M. [2014]: A Survey of Public Opinion about Autonomous and Self-driving Vehicles in the U. S., the U. K., and Australia. The University of Michigan Transportation Research Institute, Ann Arbor, https://deepblue.lib.umich.edu/handle/ 2027.42/108384.

Schoettle, B.-Sivak, M. [2016]: Motorist's Preferences for Different Levels of Vehicle Automation. The University of Michigan Transportation Research Institute, Ann Arbor, https:// deepblue.lib.umich.edu/bitstream/handle/2027.42/114386/103217.pdf.

SchomberG, R. von [2011]: Prospects for technology assessment in a framework of responsible research and innovation. Megjelent: Beecroft, M.-Dusseldorp, $R$. (szerk.): Technikfolgen Abschätzen Lehren: Bildungspotenziale Transdisziplinärer. VS Verlag, Wiesbaden, 39-61. o. https://doi.org/10.1007/978-3-531-93468-6_2.

Schreurs, M. A.-Steuwer, S. D. [2016]: Autonomous Driving: Political, Legal, Social and Sustainability Dimensions. Megjelent: Maurer, M.-Gerdes, J. C.-Lenz, B.-Winner, H. (szerk.): 
Autonomous Driving: Technical, Legal and Social Aspects. SpringerOpen, 149-171. o. https://doi.org/10.1007/978-3-662-48847-8_8.

Schuh, G.-Anderl, R.-Gausemeier, J.-Ten Hompel, M.-Wahlster, W. [2017]: Industrie 4.0 Maturity Index: Managing the Digital Transformation of Companies. Acatech Study. München, https://www.acatech.de/wp-content/uploads/2018/03/acatech_STUDIE_ Maturity_Index_eng_WEB.pdf.

Schuster, K.-Gross, K.-Vossen, R.-Richert, A.-Jeschke, S. [2015a]: Preparing for Industry 4.0: Collaborative Virtual Learning Environments in Engineering Education. Automation, Communication and Cybernetics in Science and Engineering 2015/2016. Springer International Publishing.

Schuster, K.-Plumanns, L.-Gross, K.-Vossen, R.-Richert, A.-Jeschke, S. [2015b]: Preparing for Industry 4.0: Testing Collaborative Virtual Learning Environments with Students and Professional Trainers. International Journal of Advanced Corporate Learning, Vol. 8. No. 4. 14-20. o. https://doi.org/10.3991/ijac.v8i4.4911.

Schwab, K. [2017]: The Fourth Industrial Revolution. The Crown Publishing Group, New York, NY.

Smit, J.-Kreutzer, S.-Moeller, C.-Carlberg, M. [2016]: Industry 4.0: Study for the ITRE Committee. European Parliament Directorate General for Internal Policies, Brüsszel, http://www.europarl.europa.eu/RegData/etudes/STUD/2016/570007/IPOL_ STU(2016)570007_EN.pdf.

Smith, A.-Anderson, M. [2017]: Automation in Everyday Life. Pew Research Center, Washington.

SMMT [2017a]: Connected and Autonomous Vehicles: Revolutionising Mobility in Society. The Society of Motor Manufacturers and Traders, London.

SMMT [2017b]: Connected and Autonomous Vehicles. Position Paper. The Society of Motor Manufacturers and Traders, London.

Stahl, B. C.-Coeckelbergh, M. [2016]: Ethics of healthcare robotics. Towards responsible research and innovation. Robotics and Autonomous Systems, Vol. 86. No. 12. 152-161. o. https://doi.org/10.1016/j.robot.2016.08.018.

Stilgoe, J.-Owen, R.-Macnaghten, P. [2013]: Developing a framework for responsible innovation. Research Policy, Vol. 42. No. 9. 1568-1580. o. https://doi.org/10.1016/j. respol.2013.05.008.

Sutcliffe, H. [2013]: A Report on Responsible Research and Innovation. Matter, London. Thomson, J. J. [1985]: The Trolley Problem. The Yale Law Journal, Vol. 94. No. 6. 1395-1415. o.

Tinon, A.-Ingham, M. [2011]: The societal system and responsible innovations: Freeing sustainable development from a deadlock. Journal of Innovation Economics, Vol. 8. No. 2. 11-31. o. https://doi.org/10.3917/jie.008.0011.

Trappl, R. [2016]: Ethical Systems for Self-driving Cars: An Introduction. Applied Artificial Intelligence, Vol. 30. No. 8. 745-747. o. https://doi.org/10.1080/08839514.2016.1 229737.

WEF [2017]: Realizing Human Potential in the Fourth Industrial Revolution: An Agenda for Leaders to Shape the Future of Education, Gender and Work. White Paper. World Economic Forum, Cologny.

WEF-BCG [2018]: Reshaping Urban Mobility with Autonomous Vehicles: Lessons from the City of Boston. World Economic Forum and The Boston Consulting Group, http:// www3.weforum.org/docs/WEF_Reshaping_Urban_Mobility_with_Autonomous_ Vehicles_2018.pdf. 
Winkle, T. [2016]: Development and Approval of Automated Vehicles: Considerations of Technical, Legal and Economic Risks. Megjelent: Maurer, M.-Gerdes, J. C.-Lenz, B.Winner, H. (szerk.): Autonomous Driving: Technical, Legal and Social Aspects. SpringerOpen, 589-618. o. https://doi.org/10.1007/978-3-662-48847-8_28.

Wübbeke, J.-Meissner, M.-Zenglein, M. J.-Ives, J.-Conrad, B. [2016]: Made in China 2025: The Making of a High-Tech Superpower and Its Implications for Industrial Countries. Mercator Institute for China Studies, Berlin.

Yan, C.-Xu, W.-Liu, J. [2016]: Can You Trust Autonomous Vehicles: Contactless Attacks Against Sensors of Self-driving Vehicle. DEF CON 24 Conference, Las Vegas, NV.

Yeomans, G. [2014]: Autonomous Vehicles. Handing Over Control: Opportunities and Risks for Insurance. Lloyd's, London.

Yoon, D. [2017]: What We Need to Prepare for the Fourth Industrial Revolution. Healthcare Informatics Research, Vol. 23. No. 2. 75-76. o. https://doi.org/10.4258/hir.2017.23.2.75. 